\title{
Low Ethanol Sensitivity and Increased Ethanol Consumption in Mice Lacking Adenosine $A_{2 A}$ Receptors
}

\author{
Mickaël Naassila, ${ }^{1}$ Catherine Ledent, ${ }^{2}$ and Martine Daoust ${ }^{1}$ \\ 1 Laboratoire de Physiologie-Alcoologie, Université de Picardie Jules Verne, Faculté de Pharmacie, 80000 Amiens, France, \\ and 2Institut de Recherche Interdisciplinaire, Université Libre de Bruxelles, B-1070 Brussels, Belgium
}

We have shown previously that the severity of handling-induced convulsions during ethanol withdrawal was reduced in $A_{2 A}$ receptor knock-out $\left(A_{2 A} R^{-\prime-}\right)$ mice. In the present report, we further characterize the role of adenosine $A_{2 A}$ receptors in ethanol consumption and neurobiological responses to this drug of abuse. Male $A_{2 A} R^{-1-}$ mice showed increased consumption of solutions containing 6 and $20 \%(\mathrm{~V} / \mathrm{v})$ ethanol compared with wild-type $\left(A_{2 A} R^{+/+}\right)$control mice; female $A_{2 A} R^{-1-}$ mice showed increased consumption of solutions containing 6 and $10 \%$ ethanol. This slightly higher ethanol consumption was also related to increased ethanol preference. In contrast, $A_{2 A} R^{-1-}$ mice showed normal consumption of solutions containing either sucrose or quinine. Relative to $A_{2 A} R^{+/+}$mice, $A_{2 A} R^{-1-}$ mice were found to be less sensitive to the sedative effect of $3.0 \mathrm{gm} / \mathrm{kg}$ ethanol, as measured by more rapid recovery from ethanol-induced loss of righting reflex, and to the hypothermic effects of $1.5,3.0$, and $4.0 \mathrm{gm} / \mathrm{kg}$ ethanol, al- though plasma ethanol levels did not differ significantly between the two genotypes. The selective adenosine $A_{2 A}$ receptor antagonist ZM 241385 (4-(2-[7-amino-2-(2-furyl)[1,2,4]triazolo [2,3-a][1,3,5]triazin-5-ylamino]ethyl)phenol) (10-30 mg/kg) significantly attenuated ethanol-induced $(4.0 \mathrm{gm} / \mathrm{kg})$ hypothermia in CD1 mice. To assess whether ethanol administration would induce differential tolerance in $A_{2 A} R^{-\prime-}$ and wild-type mice, we administered ethanol $(3.0 \mathrm{gm} / \mathrm{kg})$ over 4 consecutive days and found no difference in the development of tolerance; however, female $A_{2 A} R^{-1-}$ mice showed a lower tolerance-acquisition rate. These data suggest that activating the $A_{2 A}$ receptors may play a role in suppressing alcohol-drinking behavior and is associated with the sensitivity to the intoxicating effects of acute ethanol administration.

Key words: adenosine; $A_{2 A}$ receptor; ethanol; hypothermia; knock-out mice; sensitivity; tolerance; ZM 241385
Extracellular adenosine is an important signaling molecule that modulates diverse neuronal functions via four G-protein-coupled receptor subtypes: the $A_{1}, A_{2 A}, A_{2 B}$, and $A_{3}$ receptors (Fredholm et al., 2001). This neuromodulator can either inhibit or facilitate synaptic transmission via $A_{1}$ and $A_{2 A}$ receptor $\left(A_{2 A} R\right)$ activation, respectively. In the brain, the distribution of $A_{2 A} R s$ is primarily restricted to the striatum and nucleus accumbens (Jarvis and Williams, 1989), which is consistent with the proposed role of these receptors in modulating dopaminergic neurotransmission. In these regions, $\mathrm{A}_{2 \mathrm{~A}} \mathrm{R}$ activation has been shown to stimulate dopamine release and/or synthesis (Onali et al., 1988; Okada et al., 1996, 1997) [although this effect has not been replicated in the study by Jin and Fredholm (1997)] and negatively modulate the postsynaptic effects of dopamine (Ferré et al., 1991, 1993).

There is strong evidence for an involvement of the adenosinergic system in some of the central effects of ethanol at the cellular and molecular levels (Diamond and Gordon, 1994) and also at the behavioral level. In this regard, $\mathrm{A}_{1}$ and $\mathrm{A}_{2 \mathrm{~A}}$ receptors have been shown to be involved in mediating ethanol-induced motor incoordination in the rat, with a predominant role of the $\mathrm{A}_{1}$ receptor, by the use of agonists and antagonists (Meng and Dar, 1995) and antisense oligodeoxynucleotide specifically di-

Received July 15, 2002; revised Sept. 3, 2002; accepted Sept. 18, 2002.

This work was supported by Conseil Régional de Picardie (Fonds Européens de Développement Régional) funds. We thank Stephane Delanaud for his technical assistance.

Correspondence should be addressed to Dr. Mickaël Naassila, Laboratoire de Physiologie-Alcoologie, Université de Picardie Jules Verne, Faculté de Pharmacie, 1 rue des Louvels, 80000 Amiens, France. E-mail: mickael.naassila@u-picardie.fr. Copyright (C) 2002 Society for Neuroscience $0270-6474 / 02 / 2210487-07 \$ 15.00 / 0$ rected against the $\mathrm{A}_{1}$ receptor (Phan et al., 1997; Nyce, 1999). In mice, chronic ingestion of the nonselective antagonist caffeine has been shown to reduce the locomotor stimulant effects of ethanol (Daly et al., 1994). In addition, single and repeated episodes of ethanol withdrawal have been shown to increase $A_{1}$ but not $A_{2}$ receptor density in the mouse brain (Jarvis and Becker, 1998).

Recently, an $\mathrm{A}_{2 \mathrm{~A}} \mathrm{R}$ knock-out mouse has been characterized as being hypertensive, aggressive, anxious, and hypoalgesic (Ledent et al., 1997); we have shown that the severity of handling-induced convulsions during ethanol withdrawal was reduced in this $\mathrm{A}_{2 \mathrm{~A}} \mathrm{R}$ knock-out mouse (El Yacoubi et al., 2001). This mouse model has also been shown to be characterized by a functional hypodopaminergic state corresponding to a $45 \%$ decrease in the extracellular concentration of dopamine in the striatum, associated with upregulation of D1 and D2 dopamine receptor expression (Dassesse et al., 2001). Because the dopaminergic neurotransmission between the ventral tegmental area and the limbic forebrain is a critical neurobiological component of alcohol and drug selfadministration (Di Chiara and Imperato, 1988; Weiss and Porrino, 2002), brain $\mathrm{A}_{2 \mathrm{~A}}$ adenosine receptors may provide a novel target for the modulation of alcohol drinking behavior. Ethanol self-administration is decreased in D1- or D2-deficient mice (ElGhundi et al., 1998; Risinger et al., 2000), and the highly alcoholpreferring C57BL/6J mouse strain (Belknap et al., 1993) has been shown to present low nigrostriatal/mesolimbic dopaminergic activity (George et al., 1995), so that the low availability of synaptic dopamine has been postulated to increase ethanol preference.

Because $A_{2 A} \mathrm{R}$ knock-out mice have been characterized by a functional hypodopaminergic state, we postulated that these mice 
would display increased alcohol drinking and altered sensitivity and tolerance to some ethanol effects.

To more clearly understand the role of the $\mathrm{A}_{2 \mathrm{~A}} \mathrm{R}$ in mediating the effects of ethanol, we studied ethanol consumption and the hypothermic/sedative effects of ethanol in $\mathrm{A}_{2 \mathrm{~A}} \mathrm{R}$ knock-out mice. We also investigated the effect of a selective $A_{2 A} R$ antagonist on ethanol-induced hypothermia in CD1 mice.

\section{MATERIALS AND METHODS}

Animals. Adult female and male wild-type and $\mathrm{A}_{2 \mathrm{~A}} \mathrm{R}^{-1-}$ mice $(8-14$ weeks of age) generated on a CD1 background as described previously (Ledent et al., 1997) and weighing 20-30 gm were used. The firstgeneration chimeric $(129 \mathrm{SvJ} \times \mathrm{CD} 1)$ heterozygotes were bred for 15 generations on a CD1 (Charles River, St. Germain sur l'Arbresle, France) outbred background, to dilute the genetic background of the embryonic stem cells derived from the $129 \mathrm{SvJ}$ mouse strain, with selection for the mutant $\mathrm{A}_{2 \mathrm{~A}}$ gene at each generation. Fifteenth-generation heterozygotes were bred together to generate $\mathrm{A}_{2 \mathrm{~A}} \mathrm{R}$-deficient and control mice. All animals used in a given experiment originated from the same breeding series and were matched for age and weight. Experiments were also performed on adult male albino CD1 mice (Charles River, Saint Aubin les Elbeuf, France). Mice were housed in groups of 10 in clear plastic cages and maintained in a temperature-controlled $\left(\sim 22^{\circ} \mathrm{C}\right)$ and humidity-controlled room on a $12 \mathrm{hr}$ light/dark cycle. The number of animals was kept to a minimum. All efforts were made to avoid making the animals suffer; the procedures described comply with ethical principles and guidelines for the care and use of laboratory animals adopted by the European Community, law 86/609/European Economic Community.

Alcohol intake test. Data for the alcohol intake study were collected from two experiments. Throughout the experiments, fluid intake and body weight were assessed every $2 \mathrm{~d} . \mathrm{A}_{2 \mathrm{~A}} \mathrm{R}^{-1-}$ mice (male, $n=34$; female, $n=19$ ) and $\mathrm{A}_{2 \mathrm{~A}} \mathrm{R}^{+/+}$mice (male, $n=29$; female, $n=18$ ) were individually housed in plastic mouse cages with access ad libitum to standard rodent chow and habituated in their home cage to drinking from two bottles containing plain water for 1 week. Mice were then given access for $48 \mathrm{hr}$ to two bottles, one containing water and the other containing ethanol in water. The ethanol concentration $(\mathrm{v} / \mathrm{v})$ was increased every $6 \mathrm{~d}$; mice received 3, 6, 10, and finally $20 \%$ ethanol over the course of the experiment. The positions of the bottles were changed every $2 \mathrm{~d}$ to control for position preferences. Average ethanol consumption per day was obtained for each ethanol concentration. To obtain a measure of ethanol consumption that corrected for individual differences in mouse size, grams of ethanol consumed per kilogram of body weight per day were calculated for each mouse. As a measure of relative ethanol preference, an ethanol preference ratio was calculated by dividing the total ethanol solution consumed by total fluid (ethanol plus water) consumption. Two-way $2 \times 4$ (genotype $\times$ concentration) and $2 \times 3$ (genotype $\times$ trial) ANOVAs were used for statistical analysis.

Sucrose and quinine consumption test. $\mathrm{A}_{2 \mathrm{~A}} \mathrm{R}^{-1-}$ (male, $n=8$; female, $n=8$ ) and wild-type (male, $n=8$; female, $n=8$ ) mice were habituated in their home cage to drinking from two bottles containing water for 1 week and were then given plain water in one bottle and sucrose or quinine in the other bottle. The compounds were presented in the following order: sucrose solutions $(1.70$ and $4.25 \%)$ followed by quinine solutions $(0.03$ and $0.10 \mathrm{~mm})$. Mice had $48 \mathrm{hr}$ of access to each solution, and the position of the solution was counterbalanced between animals. The preference for each solution was assessed by dividing the volume of the taste solution consumed by the total volume of fluid (water plus taste solution) consumed to obtain a preference ratio. The data collected with each taste solution were analyzed separately with two-way $2 \times 2$ (genotype $\times$ concentration) repeated-measures ANOVA.

Test for sensitivity to the sedative/hypnotic effects of ethanol. $\mathrm{A}_{2 \mathrm{~A}} \mathrm{R}^{-/-}$ (male, $n=20$; female, $n=20$ ) and wild-type (male, $n=25$; female, $n=$ 21) mice were removed from their home cage and given an intraperitoneal injection of ethanol [3.0 and $4.0 \mathrm{gm} / \mathrm{kg}, 20 \%(\mathrm{w} / \mathrm{v})$ mixed in isotonic saline]. At the onset of ethanol-induced sedation, each mouse was placed on its back in a plastic U-shaped trough. The time (in minutes) that elapsed between the ethanol injection and when the mouse could right itself onto all four paws, measured three times within a $30 \mathrm{sec}$ interval, was used as the index of time to regain the righting reflex. These data were analyzed with a Student's $t$ test.

Test for sensitivity and tolerance to ethanol-induced hypothermia. To measure hypothermia to acute ethanol administration, rectal tempera- ture was measured using a KJT thermocouple (Bioseb, Paris, France) at room temperature $\left(22^{\circ} \mathrm{C}\right)$ before and after an intraperitoneal ethanol injection. Three ethanol doses were tested: $1.5,3.0$, and $4.0 \mathrm{gm} / \mathrm{kg}$ body weight $[20 \%$ ethanol $(\mathrm{w} / \mathrm{v})$ mixed in isotonic saline]. Rectal temperature was assessed every 30 min after ethanol administration.

A $4 \mathrm{~d}$ tolerance paradigm was used to assess whether ethanol administration could induce differential tolerance development in $\mathrm{A}_{2 \mathrm{~A}} \mathrm{R}^{-/-}$ and wild-type mice. Immediately after recording the baseline temperature on day 1, all mice, $\mathrm{A}_{2 \mathrm{~A}} \mathrm{R}^{-/-}$(male, $n=10$; female, $n=8$ ) and wild type (male, $n=8$; female, $n=13$ ), received an intraperitoneal injection of $3.0 \mathrm{gm} / \mathrm{kg}$ ethanol [20\% (w/v) mixed in isotonic saline]. Injections and testing were conducted daily for 4 consecutive days, and tolerance development was analyzed at $30,60,90$, and 120 min after the injection of ethanol. Two-way $2 \times 4$ (genotype $\times$ day) ANOVA and Student's $t$ test for the comparison of slopes were used for statistical analysis. It should be noted that our paradigm was used to measure behavioral tolerance, but the development of metabolic tolerance was not analyzed. To verify that the absence of the $\mathrm{A}_{2 \mathrm{~A}}$ receptor in knock-out mice could be mimicked by the administration of drugs, we also tested the effect of the selective $\mathrm{A}_{2 \mathrm{~A}}$ receptor antagonist 4-(2-[7-amino-2-(2-furyl)[1,2,4]triazolo[2,3-a][1,3,5]triazin-5-ylamino]ethyl)phenol (ZM 241385) (Sigma Aldrich, Paris, France) (Poucher et al., 1995) on ethanol-induced (4.0 $\mathrm{gm} / \mathrm{kg}$ ) hypothermia. The compound was dissolved in DMSO (15\%), stabilized with Cremophor EL (15\%), diluted in $0.9 \%$ saline $(70 \%)$, prepared fresh daily, and administered intraperitoneally 15 min before ethanol injection. One group of mice received vehicle (15\% DMSO, 15\% Cremophor EL, $70 \% \mathrm{NaCl} 0.9 \%$ ) 15 min before ethanol injection.

Plasma ethanol concentrations. We took $\sim 20 \mu \mathrm{l}$ of tail blood samples at the indicated time points after an intraperitoneal injection of ethanol (4.0 $\mathrm{gm} / \mathrm{kg}$ body weight) [20\% (w/v) prepared in saline]. Samples were microcentrifuged for $10 \mathrm{~min}(14,000 \mathrm{rpm})$ at $4^{\circ} \mathrm{C}$ and analyzed immediately. Plasma ethanol was determined by an alcohol dehydrogenase/ reduced nicotinamide adenine dinucleotide assay (Sigma Diagnostic, Paris, France) according to the manufacturer's instructions. An ethanol standard solution $(0.08 \%)$ was used to generate a standard curve (and linear regression analysis) for each experiment, and plasma ethanol levels were calculated in milligrams per deciliter. Two-way $2 \times 2$ (time $\times$ genotype) ANOVAs were used for statistical analysis.

\section{RESULTS}

\section{Alcohol, sucrose, and quinine consumption tests}

Male $\mathrm{A}_{2 \mathrm{~A}} \mathrm{R}^{-1-}$ mice consumed significantly more ethanol (grams per kilogram per $24 \mathrm{hr})$ than wild-type mice $\left(F_{(1,692)}=15.22 ; p<\right.$ $0.001)$; their preference ratios were also significantly greater $\left(F_{(1,692)}=5.97 ; p=0.01\right)$ (Fig. $\left.1 a, b\right)$. Male $\mathrm{A}_{2 \mathrm{~A}} \mathrm{R}^{-/-}$mice drank significantly more 6 and $20 \%$ ethanol solutions $(p<0.001$ and $p=0.004$, respectively).

Female $\mathrm{A}_{2 \mathrm{~A}} \mathrm{R}^{-1-}$ mice consumed significantly more ethanol than the wild-type mice $\left(F_{(1,385)}=6.48 ; p=0.01\right)$; their preference ratios were also significantly greater $\left(F_{(1,385)}=3.87 ; p=\right.$ 0.04) (Fig. 1a,b). Female $\mathrm{A}_{2 \mathrm{~A}} \mathrm{R}^{-/-}$mice drank significantly more 6 and $10 \%$ ethanol solutions $(p<0.05)$.

To determine whether these differences might reflect a more global change in taste preferences, we tested $\mathrm{A}_{2 \mathrm{~A}} \mathrm{R}^{-1-}$ and wildtype mice with sucrose and quinine solutions, using the same protocol as above. No significant difference between the genotypes was observed for the consumption of either sucrose (male, $F_{(1,56)}=2.89, p=0.09$; female, $\left.F_{(1,56)}=0.09, p=0.76\right)$ or quinine (male, $F_{(1,126)}=2.34, p=0.12$; female, $F_{(1,136)}=0.58$, $p=0.44)$ solutions, showing that the increased consumption of alcohol by $\mathrm{A}_{2 \mathrm{~A}} \mathrm{R}$ knock-out mice does not appear to be associated with an altered taste preference or caloric need (Fig. 2a,b). The preference ratios obtained in the present study are similar to values published previously (Thiele et al., 1998, Wand et al., 2001).

Total fluid consumption (in milliliters) indicated that mutant and wild-type mice did not differ in terms of the volume of fluid consumed (data not shown), indicating that the increased ethanol 


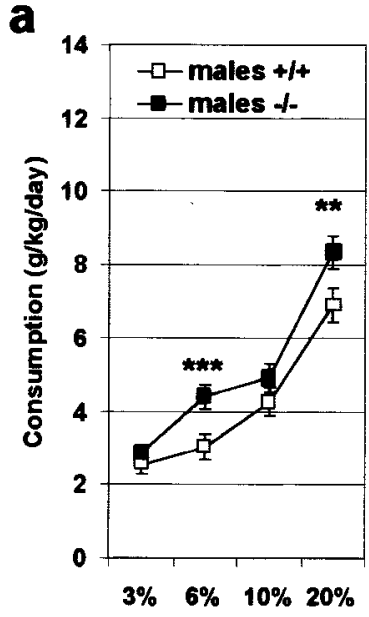

Ethanol solution $(v / v)$

b

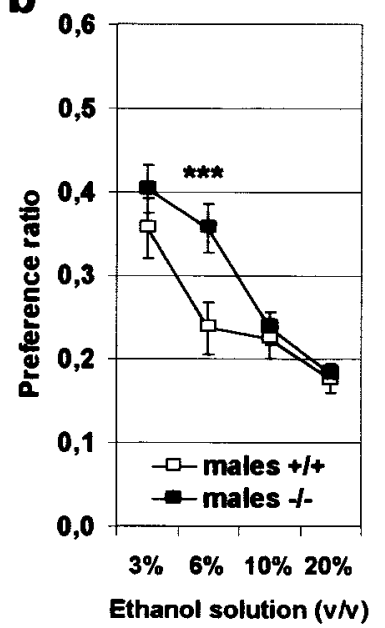

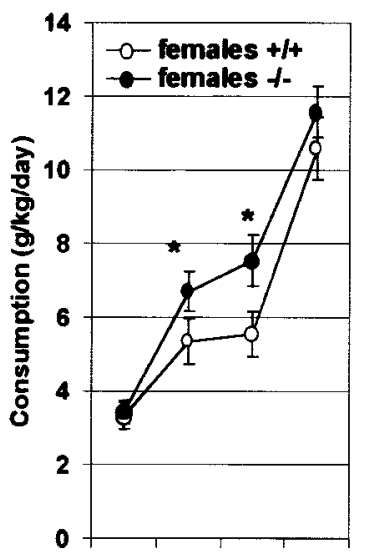

$3 \% \quad 6 \% \quad 10 \% 20 \%$ Ethanol solution (v/v)

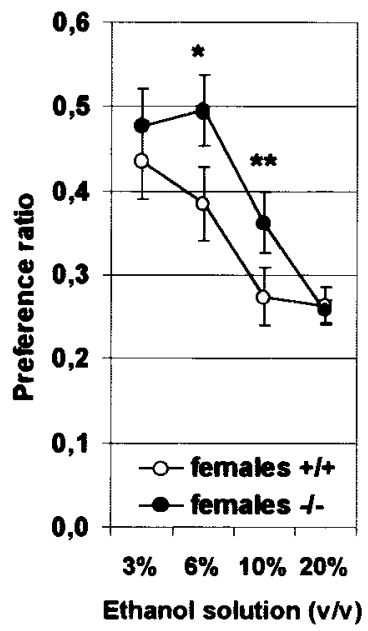

Figure 1. Ethanol consumption and preference in $\mathrm{A}_{2 \mathrm{~A}} \mathrm{R}^{-/-}$(male, $n=$ 34; female, $n=19$ ) and $\mathrm{A}_{2 \mathrm{~A}} \mathrm{R}^{+/+}$(male, $n=29$; female, $n=18$ ) mice. $a$, Consumption (grams per kilogram per day) of each ethanol solution (average of $6 \mathrm{~d}$ ). $b$, Ethanol preference ratios (volume of ethanol consumed/total volume of fluid consumed) as a measure of relative ethanol preference during the consumption of each ethanol solution. All values are means \pm SEM. ANOVAs indicated that male $\mathrm{A}_{2 \mathrm{~A}} \mathrm{R}^{-/-}$mice drank significantly more 6 and $20 \%$ ethanol solutions, and that female $\mathrm{A}_{2 \mathrm{~A}} \mathrm{R}^{-1-}$ mice drank significantly more 6 and $10 \%$ ethanol solutions than their wild-type littermate control mice; ${ }^{*} p<0.05$; $* * p<0.01$; ***p $p<0.001$.

consumption by the null mutants was not caused by an overall increase in the total amount of fluid consumed. There was also a significant effect of gender, with female mice consuming more ethanol than male mice $\left(\mathrm{A}_{2 \mathrm{~A}} \mathrm{R}^{-/-}, F_{(1,586)}=46.25, p<0.001\right.$; $\left.\mathrm{A}_{2 \mathrm{~A}} \mathrm{R}^{+/+}, F_{(1,491)}=32.78, p<0.001\right)$; preference ratios were also significantly greater in the female mice $\left(\mathrm{A}_{2 \mathrm{~A}} \mathrm{R}^{-1-}, F_{(1,586)}=\right.$ $\left.20.73, p<0.001 ; \mathrm{A}_{2 \mathrm{~A}} \mathrm{R}^{+/+}, F_{(1,491)}=12.76, p<0.001\right)$.

\section{Ethanol-induced sedation and hypothermia and plasma ethanol levels}

Male and female $\mathrm{A}_{2 \mathrm{~A}} \mathrm{R}^{-1-}$ mice were less sensitive to the sedative effects of ethanol, regaining their righting reflex sooner than $\mathrm{A}_{2 \mathrm{~A}} \mathrm{R}^{+/+}$mice after the injection of the $3.0 \mathrm{gm} / \mathrm{kg}$ ethanol dose $\left(F_{(3,86)}=17.64 ; p<0.001\right)$; however, no difference was observed after the injection of the $4.0 \mathrm{gm} / \mathrm{kg}$ ethanol dose $\left(F_{(3,80)}=0.01\right.$; $p=0.90$ ) (Fig. 3). A gender effect was also observed at the 3.0 $\mathrm{gm} / \mathrm{kg}$ ethanol dose but not at the $4.0 \mathrm{gm} / \mathrm{kg}$ dose, revealing that

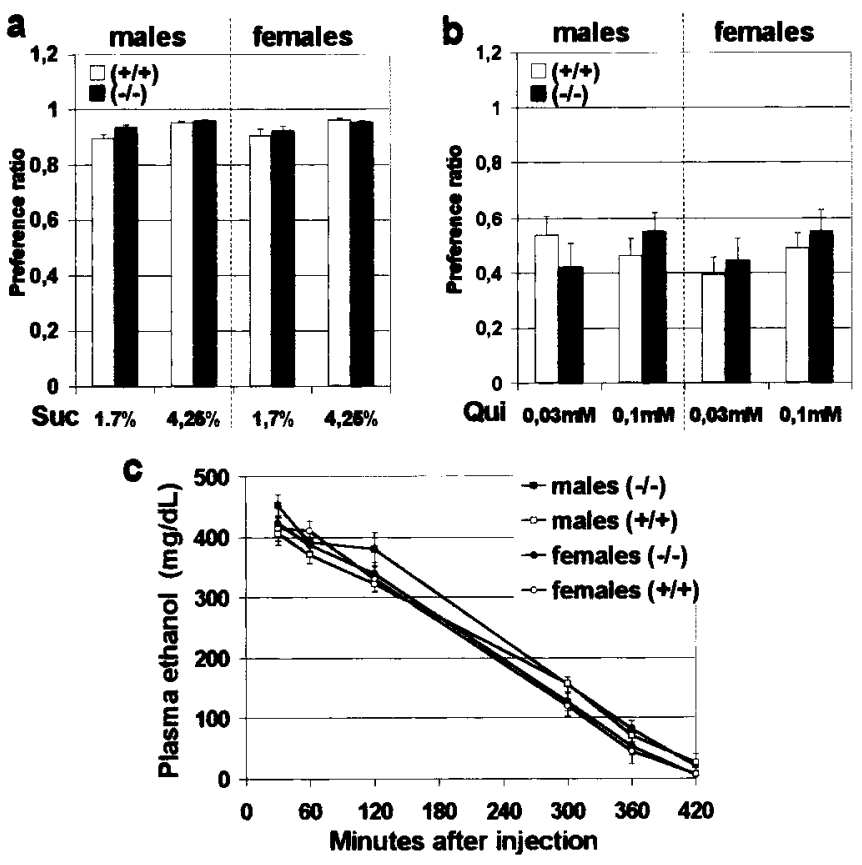

Figure 2. $a, b$, Preference ratios for sucrose (Suc) and quinine (Qui) (volume of taste solution consumed/total volume of fluid consumed) in $\mathrm{A}_{2 \mathrm{~A}} \mathrm{R}^{-/-}$(male, $n=8$; female, $n=8$ ) and $\mathrm{A}_{2 \mathrm{~A}} \mathrm{R}^{+/+}$(male, $n=8$; female, $n=8$ ) mice. $c$, Plasma ethanol concentration after ethanol injection (4.0 $\mathrm{gm} / \mathrm{kg}$, i.p.). All values are means $\pm \operatorname{SEM}(n=6$ mice in each group). ANOVAs indicated that there were no significant genotype differences for either sucrose and quinine preference ratios or ethanol metabolism.

male mice were more sensitive to the hypnotic effects of ethanol than female mice at the $3.0 \mathrm{gm} / \mathrm{kg}$ dose $\left(3.0 \mathrm{gm} / \mathrm{kg}, F_{(3,86)}=\right.$ $\left.26.64, p<0.001 ; 4.0 \mathrm{gm} / \mathrm{kg}, F_{(3,80)}=2.55, p=0.11\right)$.

Ethanol-induced hypothermia was dose-dependent in all groups of mice, as shown in Figure $4 a, b$. There was a significant difference for body temperature change at $2 \mathrm{hr}$ with the main effects of dose (males, $F_{(2,69)}=21.18, p<0.001$; females, $\left.F_{(2,57)}=3.60, p<0.03\right)$ and genotype (males, $F_{(1,69)}=6.93, p=0.01$; females, $F_{(1,57)}=$ $4.17, p=0.04$ ) (Fig. 4b). No main gender effect was observed for the sedative effect of the $4.0 \mathrm{gm} / \mathrm{kg}$ ethanol dose $\left(\mathrm{A}_{2 \mathrm{~A}} \mathrm{R}^{-1-}\right.$, $\left.F_{(1,225)}=2.49, p=0.12 ; \mathrm{A}_{2 \mathrm{~A}} \mathrm{R}^{+/+}, F_{(1,225)}=1.86, p=0.17\right)$. Male $\mathrm{A}_{2 \mathrm{~A}} \mathrm{R}^{-1-}$ mice were less sensitive to the hypothermic effects of ethanol than their wild-type littermates at all doses $(1.5 \mathrm{gm} / \mathrm{kg}$, $F_{(1,92)}=5.54, p=0.02 ; 3.0 \mathrm{gm} / \mathrm{kg}, F_{(1,72)}=8.94, p=0.004 ; 4.0$ $\left.\mathrm{gm} / \mathrm{kg}, F_{(1,252)}=32.62, p<0.001\right)$. In contrast, for the females, a difference in sensitivity was observed only at the highest dose of ethanol $\left(1.5 \mathrm{gm} / \mathrm{kg}, F_{(1,56)}=0.52, p=0.47 ; 3.0 \mathrm{gm} / \mathrm{kg}, F_{(1,84)}=\right.$ $\left.1.06, p=0.31 ; 4.0 \mathrm{gm} / \mathrm{kg}, F_{(1,198)}=18.24, p<0.001\right)$.

These differences in sensitivity to the sedative and hypothermic effects of ethanol (and ethanol consumption) do not appear to be secondary to differences in the acute clearance of ethanol, because plasma ethanol concentrations after $4 \mathrm{gm} / \mathrm{kg}$ ethanol administration did not differ between the genotypes (males, $F_{(1,48)}=0.05, p=$ 0.81 ; females, $\left.F_{(1,48)}=0.01, p=0.89\right)$ (Fig. $2 c$ ). Body temperature recovery was obtained after $\sim 7 \mathrm{hr}$, corresponding to the time of plasma ethanol clearance (data not shown).

\section{Effect of treatment with the selective antagonist (ZM 241385) on ethanol-induced hypothermia in male CD1 mice}

The effect of ZM 241385 was studied on male CD1 mice, corresponding to the genetic background used to generate the 


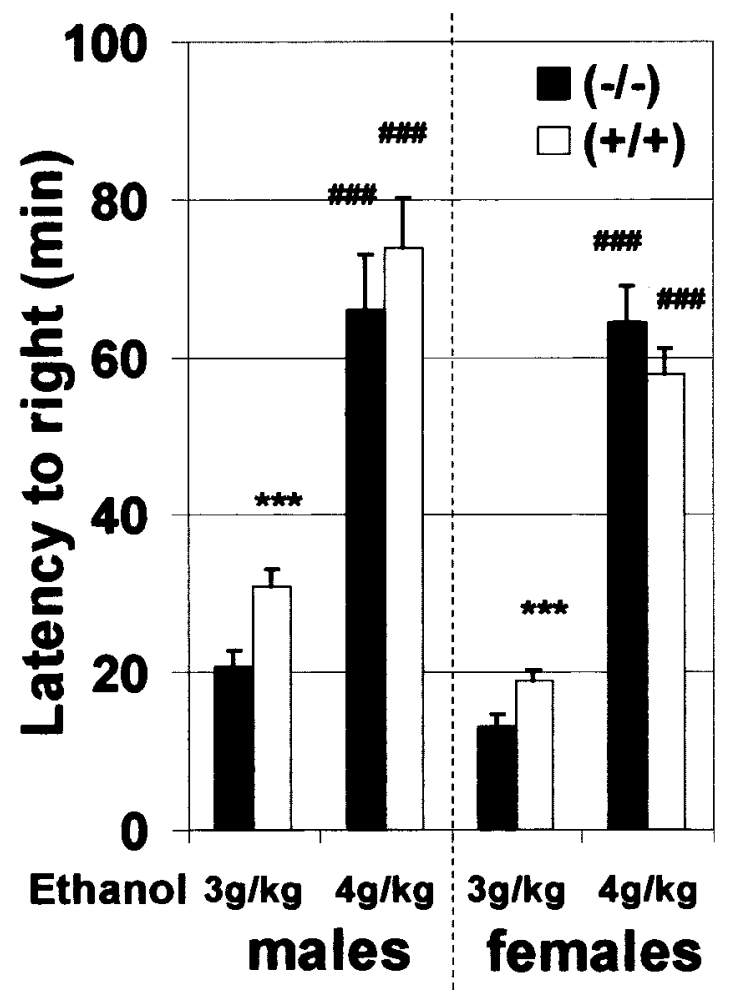

Figure 3. The time elapsed between intraperitoneal injections of ethanol ( 3.0 and $4.0 \mathrm{gm} / \mathrm{kg}$ ) and righting of the mouse on all four paws three times within a $30 \mathrm{sec}$ interval was used as an index of righting latency. All values are means \pm SEM for $\mathrm{A}_{2 \mathrm{~A}} \mathrm{R}^{-/-}$mice (male, $n=20$; female, $n=20$ ) and wild-type mice (male, $n=25$; female, $n=21$ ). ANOVA indicated that $\mathrm{A}_{2 \mathrm{~A}} \mathrm{R}^{-1-}$ mice recovered from ethanol-induced sedation significantly earlier than $\mathrm{A}_{2 \mathrm{~A}} \mathrm{R}^{+/+}$mice at the $3.0 \mathrm{gm} / \mathrm{kg}$ ethanol dose but not at the $4.0 \mathrm{gm} / \mathrm{kg}$ ethanol dose; *** $p<0.001$ compared with $\mathrm{A}_{2 \mathrm{~A}} \mathrm{R}^{+/+}$mice; $\# \#$ \# $<0.001$ compared with the respective group at the $3.0 \mathrm{gm} / \mathrm{kg}$ ethanol dose.

$\mathrm{A}_{2 \mathrm{~A}} \mathrm{R}^{-/-}$mice. The group of mice given $\mathrm{ZM} 241385$ showed a significant decrease in sensitivity to acute ethanol-induced hypothermia at the $4.0 \mathrm{gm} / \mathrm{kg}$ dose (Fig. 5). The two-way ANOVA revealed a main effect of the ZM 241385 treatment $\left(F_{(3,152)}=\right.$ $26.65 ; p<0.001)$ but no significant interaction $\left(F_{(3,152)}=0.24\right.$; $p=0.98)$ between the treatment and time factors. The difference between vehicle-treated mice and ZM 241385-treated mice was significant starting at the $20 \mathrm{mg} / \mathrm{kg}$ dose of ZM $241385\left(F_{(1,80)}=\right.$ $14.41 ; p<0.001)$. In addition, the sedative effect induced by the injection of ethanol $(4.0 \mathrm{gm} / \mathrm{kg})$ was also significantly reduced in the group of mice treated with ZM 241385 ( $21 \pm 4 \mathrm{~min}$ ), but only at the highest dose $(30 \mathrm{mg} / \mathrm{kg}$ ) (data not shown; one-way ANOVA followed by Dunn's post hoc test; $F_{(3,41)}=4.87 ; p=$ $0.005)$. A group of mice was also used to check that treatment with ZM 241385 had no effect on body temperature $\left(F_{(4,30)}=\right.$ $0.18 ; p>0.80)$.

\section{Tolerance to ethanol-induced hypothermia}

Both $\mathrm{A}_{2 \mathrm{~A}} \mathrm{R}^{-/-}$and wild-type mice developed a tolerance to 3.0 $\mathrm{gm} / \mathrm{kg}$ ethanol-induced hypothermia after repeated injections over $4 \mathrm{~d}$ (Fig. 6a,b). Two-way ANOVA showed a significant day effect at all times tested for males $\left(30 \mathrm{~min}, F_{(1,66)}=5.27, p=\right.$ $0.003 ; 60 \mathrm{~min}, F_{(1,59)}=6.79, p<0.001 ; 90 \mathrm{~min}, F_{(1,67)}=5.36, p=$ $\left.0.002 ; 120 \mathrm{~min}, F_{(1,64)}=3.21, p=0.03\right)$ and at 60,90 , and $120 \mathrm{~min}$ for females $\left(30 \mathrm{~min}, F_{(1,81)}=2.34, p=0.08 ; 60 \mathrm{~min}, F_{(1,81)}=5.65\right.$, $p=0.002 ; 90 \mathrm{~min}, F_{(1,81)}=6.35, p<0.001 ; 120 \mathrm{~min}, F_{(1,76)}=$

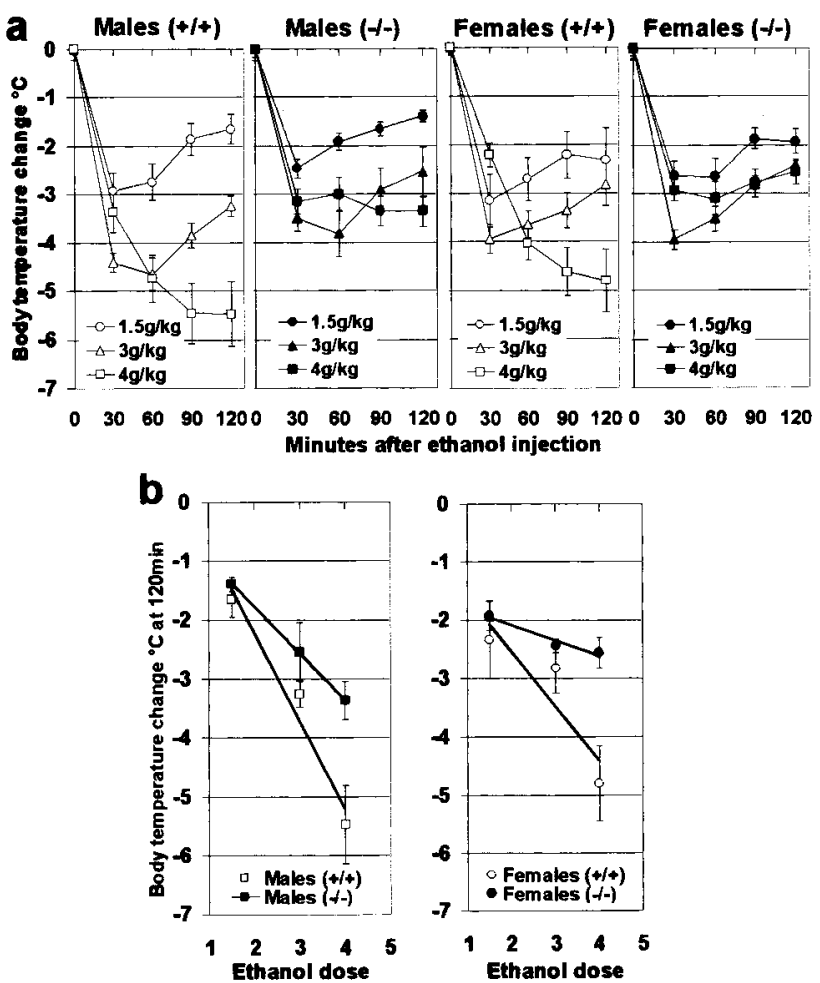

Figure 4. $a$, Mean change from baseline temperature every $30 \mathrm{~min}$ for 2 hr after the intraperitoneal injection of ethanol $(1.5,3.0$, and $4.0 \mathrm{gm} / \mathrm{kg})$ in male and female $\mathrm{A}_{2 \mathrm{~A}} \mathrm{R}^{-/-}$and $\mathrm{A}_{2 \mathrm{~A}} \mathrm{R}^{+/+}$mice $(n=6-10$ mice in each group). $b$, Dose effect of ethanol on the body temperature change $2 \mathrm{hr}$ after intraperitoneal ethanol injection. All values are means \pm SEM. ANOVA indicated that ethanol-induced hypothermia was dosedependent in all groups of mice. Moreover, male $\mathrm{A}_{2 \mathrm{~A}} \mathrm{R}^{-1-}$ mice were less sensitive to the hypothermic effects of ethanol than their wild-type littermates at all doses of ethanol; female $\mathrm{A}_{2 \mathrm{~A}} \mathrm{R}^{-1-}$ mice were also less sensitive than their wild-type littermates, but only at the highest dose of ethanol.

$3.80, p=0.01)$. There was a main effect of genotype in male mice at 30,60 , and $90 \mathrm{~min}\left(30 \mathrm{~min}, F_{(1,66)}=25.65, p<0.001 ; 60 \mathrm{~min}\right.$, $F_{(1,59)}=7.57, p=0.008 ; 90 \mathrm{~min}, F_{(1,67)}=7.21, p=0.009 ; 120$ min, $\left.F_{(1,64)}=3.12, p=0.83\right)$, whereas no genotype effect was observed in females at all times tested $\left(30 \mathrm{~min}, F_{(1,81)}=0.23, p=\right.$ 0.63 ; $60 \mathrm{~min}, F_{(1,81)}=0.01, p=0.91 ; 90 \mathrm{~min}, F_{(1,81)}=0.06, p=$ $\left.0.08 ; 120 \mathrm{~min}, F_{(1,76)}=0.09, p=0.75\right)$, demonstrating a difference in the sensitivity to $3.0 \mathrm{gm} / \mathrm{kg}$ ethanol-induced hypothermia between males but not between females. No difference in the tolerance acquisition rate was observed between male $\mathrm{A}_{2 \mathrm{~A}} \mathrm{R}^{-1-}$ and wild-type mice at all times tested ( $p>0.05$; Student's $t$ test), whereas female wild-type mice had a greater tolerance acquisition rate at both 90 and $120 \mathrm{~min}$ ( $p<0.05$; Student's $t$ test).

\section{DISCUSSION}

The overall finding in this set of studies is that mice lacking the $\mathrm{A}_{2 \mathrm{~A}}$ receptor are less sensitive to the acute effects of ethanol and consume more ethanol in a two-bottle choice paradigm compared with wild-type littermate control mice.

Females of both genotypes consumed more ethanol than males (Fig. 1), consistent with published data (Middaugh et al., 1999). Female $\mathrm{A}_{2 \mathrm{~A}} \mathrm{R}^{-/-}$mice consumed significantly more of the 6 and $10 \%$ ethanol solutions, but unlike male $\mathrm{A}_{2 \mathrm{~A}} \mathrm{R}^{-/-}$mice, they did not show significant altered consumption of the $20 \%$ ethanol solution, suggesting a possible interaction between gender and 


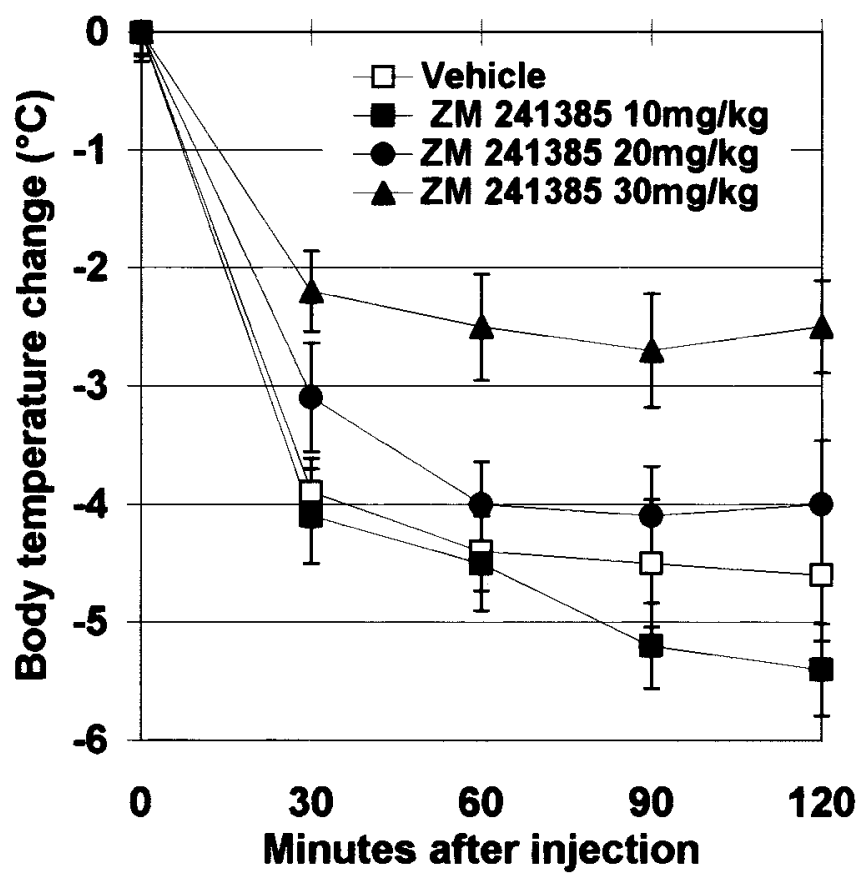

Figure 5. Effect of acute treatment with the selective $\mathrm{A}_{2 \mathrm{~A}} \mathrm{R}$ antagonist ZM 241385 (10-30 mg/kg) on ethanol-induced (4.0 gm/ kg, i.p.) hypothermia in male CD1 mice. Mice were treated with the antagonist 15 min before ethanol injection; control mice were treated with the vehicle. All values are means $\pm \operatorname{SEM}(n=10$ mice in each group $)$. ANOVA indicated that the group of mice given ZM 241385 (20-30 mg/kg) showed a significant decrease in sensitivity to acute ethanol-induced hypothermia compared with the vehicle group.

expression of phenotypes associated with the gene mutation (Fig. 1a). A similar interaction has been suggested in previous reports (Hall et al., 2001; Thiele et al., 2002). This increased ethanol consumption was also associated with an increased ethanol preference, but it is important to point out that the ethanol preference ratios were low. Therefore, the increased ethanol preference observed in the knock-out mice was not indicative of a high preference for ethanol. Both $\mathrm{A}_{2 \mathrm{~A}} \mathrm{R}^{-/-}$and $\mathrm{A}_{2 \mathrm{~A}} \mathrm{R}^{+/+}$mice preferred water to ethanol (preference ratios, $<0.50$ ); this phenotype may be dependent on the genetic background. In this regard, it has been shown previously that wild-type mice with a CD1 background had an approximately twofold decrease ( 0.29 vs 0.70$)$ in the ethanol preference ratio compared with mice with a C57BL/6 background (Wand et al., 2001). Increased ethanol consumption in $\mathrm{A}_{2 \mathrm{~A}} \mathrm{R}^{-1-}$ mice does not appear to be related to the taste of ethanol, because these mice showed normal consumption of solutions containing either sucrose or quinine (Fig. 2a,b). Furthermore, increased consumption and resistance to the acute effects of ethanol are not related to differences in ethanol metabolism, as demonstrated by the identical blood ethanol elimination curves after intraperitoneal administration in $\mathrm{A}_{2 \mathrm{~A}} \mathrm{R}^{-1-}$ and $\mathrm{A}_{2 \mathrm{~A}} \mathrm{R}^{+/+}$mice (Fig. $2 c$ ). Importantly, these data present the first direct evidence that the adenosine $\mathrm{A}_{2 \mathrm{~A}} \mathrm{R}$ is involved in ethanoldrinking behavior.

Hypothermic and sedative effects after the acute administration of ethanol have been well documented in rodents (Erwin et al., 1990); studies in rodents have supported the idea that high levels of ethanol drinking are often associated with resistance to the intoxicating effects produced by this psychoactive substance. For example, rats that have been selectively bred for high ethanol consumption (alcohol-preferring rats) are more resistant to the impairing effects of acute ethanol injection compared with nonalcohol-preferring rats (Kurtz et al., 1996). Moreover, reduced initial sensitivity to alcohol has been demonstrated in at-risk populations (for review, see Schuckit, 1987). In the present study, we report that mice lacking the $\mathrm{A}_{2 \mathrm{~A}}$ receptor are less sensitive to acute ethanol-induced hypothermia (Fig. 4) and sedation (Fig. 3), and that this resistance is associated with increased ethanol consumption. It should be noted that at the highest dose of ethanol $(4.0 \mathrm{gm} / \mathrm{kg})$, this difference in sensitivity is observed for the hypothermic effects but not for the sedative effects. These two responses to acute ethanol injection can be dissociated, because animal studies have shown that ethanol-induced hypothermia and loss of the righting reflex are polygenic traits (Erwin et al., 1990). Our results demonstrate that the difference in the acute effects of ethanol is associated with a lack of $\mathrm{A}_{2 \mathrm{~A}} \mathrm{R}$, because the effects of ethanol, both hypothermia and sedation, are reduced by acute treatment with the selective $\mathrm{A}_{2 \mathrm{~A}} \mathrm{R}$ antagonist ZM 241385 (20-30 $\mathrm{mg} / \mathrm{kg}$ ) (Fig. 5). Because the selective antagonist causes an attenuation of ethanol-induced hypothermia, it is possible to speculate that this antagonist would also increase voluntary ethanol drinking. This resistance to the acute effects of ethanol is also associated with a decrease in ethanol withdrawal-induced convulsions, because after chronic consumption of an ethanol diet, $\mathrm{A}_{2 \mathrm{~A}} \mathrm{R}^{-1-}$ mice demonstrated less severe withdrawal signs than wild-type mice, and treatment of CD1 mice with the $\mathrm{A}_{2 \mathrm{~A}}$ receptor selective antagonist ZM $241385(20 \mathrm{mg} / \mathrm{kg})$ significantly reduced the handling-induced convulsion score after chronic alcohol exposure (El Yacoubi et al., 2001).

On the one hand, these differences in ethanol consumption might be related to the basal-level anxiety differences between $\mathrm{A}_{2 \mathrm{~A}} \mathrm{R}^{-1-}$ and wild-type mice, because $\mathrm{A}_{2 \mathrm{~A}} \mathrm{R}^{-1-}$ mice have more anxiety-related behavior, as indicated by the open-field test, the elevated plus-maze test, and the black-and-white compartments test (Ledent et al., 1997). Because ethanol has anxiolytic properties (Stewart et al., 1993), it is possible that $\mathrm{A}_{2 \mathrm{~A}} \mathrm{R}^{-/-}$mice consume more ethanol to modulate anxiety. In this regard, alcohol-preferring rats have been shown to be more anxious and/or emotional than alcohol-nonpreferring rats in some tests (Stewart et al., 1993). On the other hand, because a functional striatal hypodopaminergic state has been described in $\mathrm{A}_{2 \mathrm{~A}} \mathrm{R}^{-/-}$ mice (Dassesse et al., 2001), it is possible that increased ethanol consumption is related to dysf unction of the dopaminergic system in the mesocorticolimbic reward pathway. Like most drugs of abuse, ethanol acutely elevates extracellular dopamine concentrations in the nucleus accumbens; this modulation of mesolimbic dopamine transmission represents a substrate for the positive reinforcing actions of ethanol (Di Chiara and Imperato, 1988; Koob, 1992). The threshold to the rewarding effects of ethanol could be altered in $\mathrm{A}_{2 \mathrm{~A}} \mathrm{R}^{-/-}$mice compared with their wild-type littermate controls. In this regard, selective $\mathrm{A}_{2 \mathrm{~A}} \mathrm{R}$ agonists have been found to attenuate the rewarding effects of brain stimulation, suggesting that adenosine, via $\mathrm{A}_{2 \mathrm{~A}} \mathrm{R}$, may inhibit central reward processes (Baldo et al., 1999).

The neurochemical mechanism underlying this altered behavioral response to ethanol in $\mathrm{A}_{2 \mathrm{~A}} \mathrm{R}^{-1-}$ mice is unknown. Adenosine regulates neurotransmitter release, often in a facilitatory manner, by acting via $\mathrm{A}_{2 \mathrm{~A}} \mathrm{R}$; some effects on the release of GABA, dopamine, acetylcholine, and glutamate have been reported in the striatum (for review, see Svenningsson et al., 1999). Synaptosomal preparations from transgenic mice lacking functional $\mathrm{A}_{2 \mathrm{~A}} \mathrm{R}$ show decreased dopamine release compared with 
Figure 6. Tolerance development to ethanol-induced $(3.0 \mathrm{gm} / \mathrm{kg})$ hypothermia over 4 consecutive days in male $(a)$ and female $(b) \mathrm{A}_{2 \mathrm{~A}} \mathrm{R}^{-1-}$ (male, $n=10$; female, $n=8$ ) and $\mathrm{A}_{2 \mathrm{~A}} \mathrm{R}^{+/+}$(male, $n=8$; female, $n=$ 13) mice. All values are means \pm SEM. There was no difference in the tolerance acquisition rate between male $\mathrm{A}_{2 \mathrm{~A}} \mathrm{R}^{-1-}$ and wild-type mice at all times tested ( $p>0.05$; Student's $t$ test), whereas female wild-type mice had a higher tolerance acquisition rate at both 90 and $120 \mathrm{~min}(p>0.05$; Student's $t$ test).
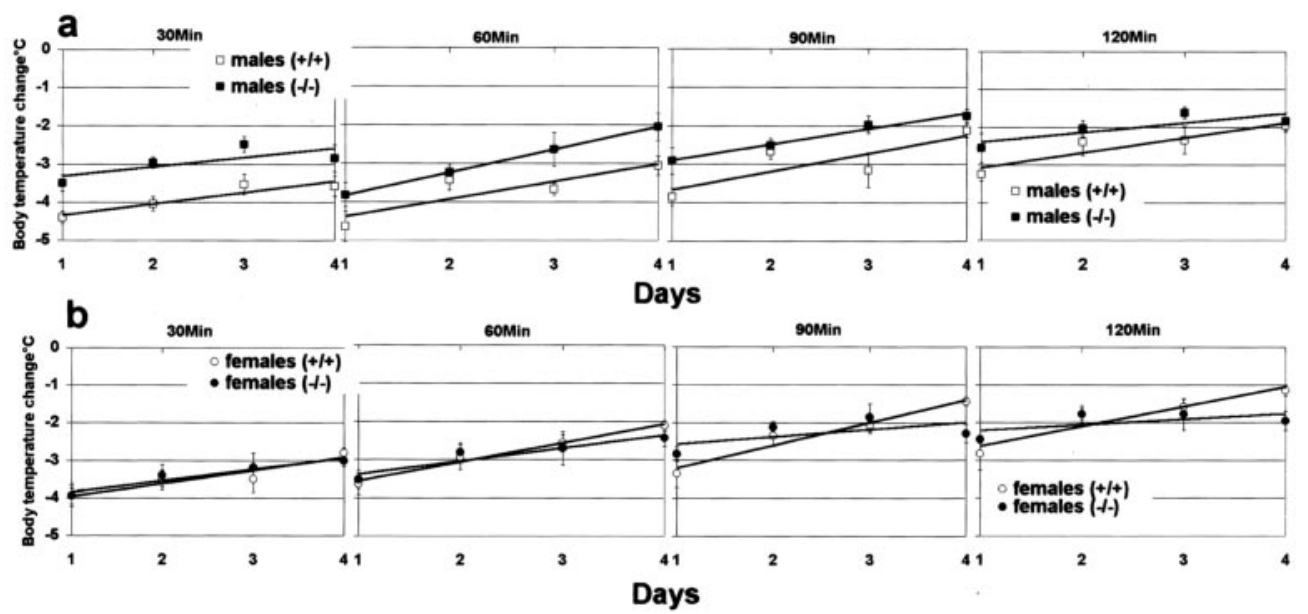

preparations from control animals (Chen et al., 1998). Therefore, $\mathrm{A}_{2 \mathrm{~A}} \mathrm{R}$ may regulate dopamine release, but the evidence has not been consistently demonstrated (Jin and Fredholm, 1997); this regulation may be secondary to the effects on the release of other neurotransmitters. Another mechanism could involve the lack of functional interaction between $\mathrm{A}_{2 \mathrm{~A}} \mathrm{R}$ and dopamine receptors in $\mathrm{A}_{2 \mathrm{~A}} \mathrm{R}^{-/-}$mice. In this regard, it has been shown that $\mathrm{A}_{2 \mathrm{~A}} \mathrm{R}$ agonists exert their actions by decreasing the affinity of dopamine D2 receptors (Ferré et al., 1991).

Repeated exposure to ethanol results in decreased responsiveness to the effects of ethanol on the CNS. This adaptation, referred to as tolerance, is observed in animals and humans and is influenced by environmental factors and by genotype in rodents. Tolerance to ethanol is a complex phenomenon, appearing in chronic, rapid, and acute forms that are largely dependent on the amount and schedule of ethanol exposure and the behavioral paradigm used to measure tolerance (Le, 1990; Khanna et al., 1993). Numerous studies have shown this phenomenon in motorimpairment and hypothermia tests. As for the decreased initial sensitivity to ethanol, increased tolerance development in humans has been associated with a risk for alcoholism (Newlin and Thomson, 1991). Our results show that the tolerance observed with our paradigm does not appear to be a good predictive factor for the high level of ethanol intake, because no clear difference in the development of tolerance was observed between $\mathrm{A}_{2 \mathrm{~A}} \mathrm{R}^{-1-}$ and $\mathrm{A}_{2 \mathrm{~A}} \mathrm{R}^{+/+}$mice (Fig. 6). All mice developed tolerance to the hypothermic effects of acute injection of ethanol $(3.0 \mathrm{gm} / \mathrm{kg})$ over 4 consecutive days. However, the greater sensitivity to ethanol observed in female $\mathrm{A}_{2 \mathrm{~A}} \mathrm{R}^{+/+}$mice was associated with the more rapid acquisition of tolerance at 90 and $120 \mathrm{~min}$ after repeated ethanol injection (Fig. 6). This association has also been described in rats, because the M520 strain that is initially more sensitive to acute alcohol incoordinating effects becomes less sensitive than the MR strain after repeated alcohol exposure (Tabakoff and Culp, 1984). This relationship was not found to be significant for the male mice in our study. The sensitivity appears to be the response to ethanol most strongly associated with ethanol preference in $\mathrm{A}_{2 \mathrm{~A}} \mathrm{R}^{-/-}$and $\mathrm{A}_{2 \mathrm{~A}} \mathrm{R}^{+/+}$mice. Differences in initial sensitivity and/or acute tolerance have also been described in alcohol-preferring C57BL/6J and non-alcoholpreferring DBA mouse strains (Tabakoff and Ritzmann, 1979).

In summary, we show that the $A_{2 A} R$ is involved in the sensitivity to the hypothermic and sedative effects of ethanol and may play a role in alcohol-drinking behavior. The present results further support that the sensitivity to ethanol is a good predictive parameter for the development of alcohol dependence. The exact role of $\mathrm{A}_{2 \mathrm{~A}} \mathrm{R}$ in this relationship needs additional investigation. It is clear that the role of the $\mathrm{A}_{2 \mathrm{~A}} \mathrm{R}$ in ethanol consumption is complex and may not be unitary but may possibly involve both interactions with the dopaminergic reward pathway and anxiety mechanisms.

\section{REFERENCES}

Baldo BA, Koob GF, Markou A (1999) Role of adenosine A2 receptors in brain stimulation reward under baseline conditions and during cocaine withdrawal in rats. J Neurosci 19:11017-11026.

Belknap JK, Crabbe JC, Young ER (1993) Voluntary consumption of ethanol in 15 inbred mouse strains. Psychopharmacology (Berl) 112:503-100.

Chen JF, Moratalla R, Turner T, Xu YH, Beilstein M, Standaert D, Penney J, Fink JS, Schwarzschild MA (1998) Deficiency of the A2 A adenosine receptor attenuates striatal dopamine release as well as spontaneous and amphetamine-induced locomotion. Soc Neurosci Abstr 24:824.11.

Daly JW, Shi D, Wong V, Nikodijevic O (1994) Chronic effects of ethanol on central adenosine function of mice. Brain Res 650:153-156.

Dassesse D, Massie A, Ferrari R, Ledent C, Parmentier M, Arckens L, Zoli M, Schiffmann SN (2001) Functional striatal hypodopaminergic activity in mice lacking adenosine $\mathrm{A}(2 \mathrm{~A})$ receptors. J Neurochem 78:183-198.

Diamond I, Gordon AS (1994) The role of adenosine in mediating cellular and molecular responses to ethanol. EXS 71:175-183.

Di Chiara G, Imperato A (1988) Drugs abused by humans preferentially increase synaptic dopamine concentrations in the mesolimbic system of freely moving rats. Proc Natl Acad Sci USA 85:5274-5278.

El-Ghundi M, George SR, Drago J, Fletcher PJ, Fan T, Nguyen T, Liu C, Sibley DR, Westphal H, O'Dowd BF (1998) Disruption of dopamine D1 receptor gene expression attenuates alcohol-seeking behavior. Eur J Pharmacol 353:149-158.

El Yacoubi M, Ledent C, Parmentier M, Daoust M, Costentin J, Vaugeois $\mathrm{J}$ (2001) Absence of the adenosine $\mathrm{A}(2 \mathrm{~A})$ receptor or its chronic blockade decrease ethanol withdrawal-induced seizures in mice. Neuropharmacology 40:424-432.

Erwin VG, Jones BC, Radcliffe R (1990) Further characterization of LS $\times$ SS recombinant inbred strains of mice: activating and hypothermic effects of ethanol. Alcohol Clin Exp Res 14:200-204.

Ferré S, von Euler G, Johansson B, Fredholm BB, Fuxe K (1991) Stimulation of high-affinity adenosine A2 receptors decreases the affinity of dopamine D2 receptors in rat striatal membranes. Proc Natl Acad Sci USA 88:7238-7241.

Ferré S, O'Connor WT, Fuxe K, Ungerstedt U (1993) The striopallidal neuron: a main locus for adenosine-dopamine interactions in the brain. J Neurosci 13:5402-406.

Fredholm BB, IJzerman AP, Jacobson KA, Klotz KN, Linden J (2001) International Union of Pharmacology. XXV. Nomenclature and classification of adenosine receptors. Pharmacol Rev 53:527-552.

George SR, Fan T, Ng G, Jung SY, O'Dowd BF, Naranjo CA (1995) Low endogenous dopamine function in brain predisposes to high alcohol preference and consumption: reversal by increasing synaptic dopamine. J Pharmacol Exp Ther 273:373-379.

Hall FS, Sora I, Uhl GR (2001) Ethanol consumption and reward are 
decreased in $\mu$-opiate receptor knockout mice. Psychopharmacology (Berl) 154:43-49.

Jarvis MF, Becker HC (1998) Single and repeated episodes of ethanol withdrawal increase adenosine $\mathrm{A} 1$, but not $\mathrm{A} 2 \mathrm{~A}$, receptor density in mouse brain. Brain Res 786:80-88.

Jarvis MF, Williams M (1989) Direct autoradiographic localization of adenosine A2 receptors in the rat brain using the A2-selective agonist, $\left[{ }^{3} \mathrm{H}\right] \mathrm{CGS}$ 21680. Eur J Pharmacol 168:243-246.

Jin S, Fredholm BB (1997) Adenosine A2A receptor stimulation increases release of acetylcholine from rat hippocampus but not striatum, and does not affect catecholamine release. Naunyn Schmiedebergs Arch Pharmacol 355:48-56.

Khanna JM, Shah G, Weiner J, Wu PH, Kalant H (1993) Effect of NMDA receptor antagonists on rapid tolerance to ethanol. Eur J Pharmacol 230:23-31.

Koob GF (1992) Drugs of abuse: anatomy, pharmacology and function of reward pathways. Trends Pharmacol Sci 3:177-184.

Kurtz DL, Stewart RB, Zweifel M, Li TK, Froehlich JC (1996) Genetic differences in tolerance and sensitization to the sedative/hypnotic effects of alcohol. Pharmacol Biochem Behav 53:585-591.

Le AD (1990) Factors regulating ethanol tolerance. Ann Med 22:265-268.

Ledent C, Vaugeois JM, Schiffmann SN, Pedrazzini T, El Yacoubi M, Vanderhaeghen JJ, Costentin J, Heath JK, Vassart G, Parmentier M (1997) Aggressiveness, hypoalgesia and high blood pressure in mice lacking the adenosine A2a receptor. Nature 388:674-678.

Meng ZH, Dar MS (1995) Possible role of striatal adenosine in the modulation of acute ethanol-induced motor incoordination in rats. Alcohol Clin Exp Res 19:892-901.

Middaugh LD, Kelley BM, Bandy AL, McGroarty KK (1999) Ethanol consumption by C57BL/6 mice: influence of gender and procedural variables. Alcohol 17:175-183.

Newlin DB, Thomson JB (1991) Chronic tolerance and sensitization to alcohol in sons of alcoholics. Alcohol Clin Exp Res 15:399-405.

Nyce JW (1999) Insight into adenosine receptor function using antisense and gene-knockout approaches. Trends Pharmacol Sci 20:79-83.

Okada M, Mizuno K, Kaneko S (1996) Adenosine A1 and A2 receptors modulate extracellular dopamine levels in rat striatum. Neurosci Lett 212:53-56

Okada M, Kiryu K, Kawata Y, Mizuno K, Wada K, Tasaki H, Kaneko S (1997) Determination of the effects of caffeine and carbamazepine on striatal dopamine release by in vivo microdialysis. Eur $\mathrm{J}$ Pharmacol 321:181-188.

Onali P, Olianas MC, Bunse B (1988) Evidence that adenosine A2 and dopamine autoreceptors antagonistically regulate tyrosine hydroxylase activity in rat striatal synaptosomes. Brain Res 456:302-309.

Phan TA, Gray AM, Nyce JW (1997) Intrastriatal adenosine A1 receptor antisense oligodeoxynucleotide blocks ethanol-induced motor incoordination. Eur J Pharmacol 323:R5-R7.

Poucher SM, Keddie JR, Singh P, Stoggall SM, Caulkett PW, Jones G, Coll MG (1995) The in vitro pharmacology of ZM 241385, a potent, non-xanthine A2a selective adenosine receptor antagonist. Br J Pharmacol 115:1096-1102.

Risinger FO, Freeman PA, Rubinstein M, Low MJ, Grandy DK (2000) Lack of operant ethanol self-administration in dopamine D2 receptor knockout mice. Psychopharmacology (Berl) 152:343-350.

Schuckit MA (1987) Biological vulnerability to alcoholism. J Consult Clin Psychol 55:301-309.

Stewart RB, Gatto GJ, Lumeng L, Li TK, Murphy JM (1993) Comparison of alcohol-preferring (P) and nonpreferring (NP) rats on tests of anxiety and for the anxiolytic effects of ethanol. Alcohol 10:1-10.

Svenningsson P, Le Moine C, Fisone G, Fredholm BB (1999) Distribution, biochemistry and function of striatal adenosine A2A receptors. Prog Neurobiol 59:355-396.

Tabakoff B, Culp SG (1984) Studies on tolerance development in inbred and heterogeneous stock National Institutes of Health rats. Alcohol Clin Exp Res 8:495-499.

Tabakoff B, Ritzmann RF (1979) Acute tolerance in inbred and selected lines of mice. Drug Alcohol Depend 4:87-90.

Thiele TE, Marsh DJ, Ste Marie L, Bernstein IL, Palmiter RD (1998) Ethanol consumption and resistance are inversely related to neuropeptide Y levels. Nature 396:366-369.

Thiele TE, Koh MT, Pedrazzini T (2002) Voluntary alcohol consumption is controlled via the neuropeptide $\mathrm{Y}$ Y1 receptor. $\mathrm{J}$ Neurosci 22:RC208(1-6).

Wand G, Levine M, Zweifel L, Schwindinger W, Abel T (2001) The cAMP-protein kinase A signal transduction pathway modulates ethanol consumption and sedative effects of ethanol. J Neurosci 21:5297-5303.

Weiss F, Porrino LJ (2002) Behavioral neurobiology of alcohol addiction: recent advances and challenges. J Neurosci 22:3332-3337. 